\title{
PASSUREQ : Learning Process; The technique of building Story and Poetry Lines, and Social Life (Analysis of Albert B. Lord's Formula)
}

\author{
Nur Kamila Suriadi \\ \{nurkamilasuriadi@yahoo.co.id\} \\ Linguistics, Graduate School Program, Hasanuddin University
}

\begin{abstract}
Passureq plays an important role in the Bugis community as a person who is trusted to be a La Galigo text reader. In addition, passureq clearly plays an important role in the outbreak of community values related to the teachings of La Galigo. This research uses formula theory approach with qualitative descriptive research type. Data collection is carried out through (1) Library Studies, (2) Interviews, and (3) Observations. In managing data, the author uses the following steps (1) collecting data from observations, interviews and documentation, (2) analyzing data after the data is collected, (3) Describing and describing reports which are the final activities of the study. Self-taught learning process passureq. At first they overheard a neighbor's cassette tape becoming a habit and finally became really interested in becoming a Passureq after he was married. The technique of presenting stories in massureq consists of: (1) constructing a story that includes the plot and story development techniques, (2) arranging lines of poetry. In the past, passureq's social life played an important role in the life of the Bugis community, especially in Wajo Regency. A passureq is considered a respectable person and always involves passureq in the celebration or activity of the community. Passureq also received support from the government in the form of materials such as financial and non-material assistance. But now it has experienced a shift. For the people of Desa Bulo passureq still has special positions that are considered important such as (1) Spiritual Advisers, (2) Teachers, and (3) Examples.
\end{abstract}

Keywords: Oral Literature

\section{Introduction}

A big nation is a nation that values its culture, this slogan we often hear is expressed by followers of multiculturalism. Massureq in the new order period must be understood as a humanitarian movement that cannot be separated from the facts of Indonesian cultural diversity that cannot be eliminated by anything including by the hands of power. The proof, in the new order period, several passureqs emerged, one of which was Indo Masse. They have a high commitment to maintaining the tradition of massureq as the local identity of the Bugis community, especially the Wajo community. Iyami nariyasekki ogi nasabaq engkaki tettong 
ko ade'e, Indo Masse is a statement describing the ideology of a passureq so firmly on the issue of maintaining the massureq tradition with the belief that customary identity is important. It is Adat that makes the identity of immorality real, meaning that the massureq tradition in the Bugis Wajo community must be maintained regardless of the conditions and challenges faced because the identity of the Bugis Wajo people is one of them constructed in the massureq tradition.

La Galigo is not only a written tradition but an oral tradition as well. Verbal action is a time to communicate and socialize all contents and values contained in La Galigo. This event is called massureq. The content can tell episodes of To Manurung, Pelayar Sawerigading, or episodes of Meong Palo. A translator can be ready to interpret and explain the meaning of ancient words developed by passureq, which is not understood by the general public [1].

La Galigo, Sawerigading, is considered or positioned as a Prophet by Pre-Islamic Bugis. The role of La Galigo as a guide to Bugis life can be in the form of a reference to all community values [2]. Set the form of community activities, for example mattanra esso, namely the belief of the Bugis community about the existence of good days to start various activities. For example, a good day to start building a house, a good day to sail for fishermen, a good day for a wedding starting from the application process until the process of implementing the event. Passureq plays an important role in the Bugis community as a person who is trusted to be a La Galigo text reader [3]. In addition, passureq clearly plays an important role in the outbreak of community values related to the teachings of La Galigo [4].

Passureq has a very important role in the Bugis community regarding the existence of $\mathrm{La}$ Galigo and its relationship with the Bugis community [5]. However, the current passureq condition is being ignored by the Bugis community group in general. Only the Bugis To Lotang tribe in Sidrap Regency and Wajo District still show this seriousness. Passureq focuses on four broad lines, namely: 1) The process of learning Passureq, namely the stages through which a person will become a passureq, including where he learns, how he learns, and whether there are special treatments in learning, 2) the composition and situation of reading Galigo, 3) Technique of building stories and composing lines of poetry, and 4) Passureq social life, namely the background of passureq life including people's response to passureq from time to time.

\section{Research Method}

The object of this research is in the village of Buloe because in that village many inhabited by people who still preserve the massureq oral tradition. The data source of this research is Indo Masse who is a passureq and cultural figures in Wajo Regency. Data collection methods used in this study are (1) Literature Study, (2) Interviews, and (3) Observations. In managing data, the writer uses a qualitative approach. Where this approach will directly illustrate the research problem about PASSUREQ: The learning process; Techniques to build stories and lines of poetry and social life. 


\section{Results And Discussion}

\subsection{Passureq Learning Process}

According to one passureq who still survives in the village of Buloe called Indo Masse, he learns self-taught, at first he used to listen to people who were massureq like his neighbors. Because he often listens to passureq, he finally feels close and tries to adopt rhythms into his jokes using his own words. The habit lasted until finally he was really interested in becoming a passureq after he married [6].

When Indo Masse experienced periods of introduction to the massureq tradition through his accidental listening to neighbors who were massureq, at that moment the memory of tone, rhythm, and melody began to build up in him. It becomes permanent when he starts to chant various words based on his listening experience. Indo Masse's actions at that time could be said to be an expression of spontaneity and in response to sensing experiences. So Indo Masse in the end really pursued the massureq tradition, but he still used traditional standards embedded in his memory. Although he has professionally studied the massureq technique. In connection with Lord's discovery of the Yoguslavian tradition, it is clear that Indo Masse also experienced the same thing that was experienced with Yoguslavian children. The difference between the two is only in the form or medium of learning. Thus it is clear that the children of Yoguslavia and the Buginese children use the same way of learning to sing, which is to judge by listening to established singers; then start to arrange lines, then bring them in a short duration. Next they will master formula techniques, which can help them in conveying story ideas. Indo Masse has the ability to do, listen, imitate, and then process his experience into a new formula that he created himself that would later become a permanent formula.

\subsection{Composition and Situation of La Galigo Reading}

Massureq as a ritual that describes the Bugis human relationship with the Gods in the process is practiced in such a sacred Starting from the preparation by holding all offerings as the main requirements. These offerings came to be known as olona Dewatae, a ritual of worship dedicated to the Gods in Boting Langi or the upper world. After this ritual of worship, the next ritual is the gendrang langu or drum beat that uses three wasps as an opening to be followed by a variety of wasps. This drum attraction marks the start of Massureq by Passureq. The manuscript of La Galigo was then opened after the drum beat of these three, to further do the reading process of the text La Galigo.

The stages of massureq implementation In stage 1 inside bere' Tudang there is coconut Otti mabbija, Tello manu kampong, Golla cella and in stage, 2 minyak kemenyang 3. maddupa-dupa 4. shroud 5. Gendrang Tellu.

The storytelling structure also has special standards in the reading process. Broadly speaking, it is divided into three stages, namely opening including greetings, prayer readings, and permission to the popular audience called mappatabe. Then the contents include a comprehensive telling of the context or theme raised, and finally the closing, which is mostly infiltrated with messages [7]. Every massureq implementation must begin with the reading of this prayer. So that there is continuous repetition, in the repetition, the formula system applies, namely about the repetition of certain themes. The theme intended in this context is belief in God or God. 


\subsection{Techniques to Build Stories and Arrange Poetry Lines}

\subsubsection{Story building techniques}

Passureq has mastered a number of scenes that are ready to use. The ready-to-use scenes are arranged in accordance with the framework of the story so that a passureq is naturally able to make innovations as an improvisation in building a story in every appearance he does. Passureq uses a formula that becomes a storytelling technique. This formula becomes an important point that enlivens the passureq's retention style. As Lord's theory says[2], the most stable example of a formula is the formula for the most common poetic ideas, namely expressing the name of the actor, event, time, and place.

Repeating the mention of certain places, for example Boting langi, peretiwi, and buri liu as a place that is often repeated mentioning starting from the opening, filling and closing. Likewise, the names of perpetrators such as Batara Guru and Sawerigading are also often repeated. Other techniques that support massureq are techniques that fully use body language or use the help of other instruments such as musical instruments or other props that are considered appropriate. This technique serves to emphasize certain words or events symbolically [8]. In the tradition of reading the text of La Galigo, and also in the tradition of the Bugis people, there are various words that refer to a character or place that is sacred tends to be considered sacred. Repeated mention will be considered to violate the real rules, so that repeated mention is considered taboo. For this reason, several repetitive words will be represented by passureq in the language of symbolic body movements. Some symbolic movements are as follows: First, the movement touches the mouth, nose, and fontanel as a symbol of the greatness of Sawerigading. This movement at a glance is just an ordinary movement.

\subsubsection{Arrange Poetry Lines}

The compilation of poetry lines uses repetition technique, which is a technique that is used by passureq repeatedly when displaying the reading of the La Galigo text. This technique fully uses speech media or certain words that have certain meanings both based on the contents of the text and based on the contextual meaning of words. For example, the frequent mention of the names of characters and events in the La Galigo story with specific goals that passureq wants to pursue. For example when passureq feels the audience's response is not good, then usually passureq will say the names of figures or events that are considered sacred in the Bugis community with the aim of attracting audience interest [9].

Passureq in chanting the La Galigo text as poetry lines when massureq performs repetition or repetition techniques as a formula. The formula triggers Passureq's memory to become like a rote memory for her. The formula used by Passureq has been structured in such a way that is structurally in their minds, so that the massureq in various places always sounds the same [10].

There are several repetition or repetition techniques found in Indo Masse as a passureq formula which is the object of this research. Among other things, the iteration technique as below;

\subsubsection{Repetition of Phrases, Sentences and Paragraphs}

The repetition of words, sentences, and paragraphs is aimed at several things, for example a marker of transitional episodes, a marker of the end of a story and the start of a story, as well as a sign of a transitional event. An example of a paragraph repetition that also functions as a marker of the end and beginning of events is a paragraph that tells the beginning of the story telling of La Galigo This section also tells the event of the rise of the Palanroe people. Repeated sentences in paragraphs are also seen in this paragraph. 


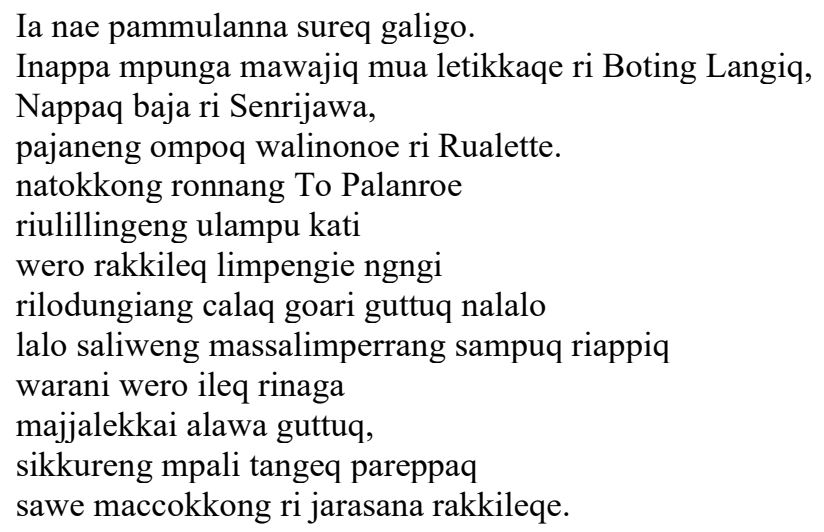

Repetition is indirectly seen in "Inappa mpunga mawajiq mua letikkaqe ri Boting Langiq, pajaneng ompoq walinonoe ri Rualette// The sun had just risen on Botinglangi. Clearly the sun shines on ruallette ". Both of these adventures describe the same purpose but do not use the same word, namely the rising of the sun. However, the intention that passureq wants to convey is Ruallette or the world above as well as a symbol of the region where the gods live, which means also the main source of all life, that the land of origin of the earth's rulers is also to illustrate that Ruallette is the source of the light. When the sun rises at Boting Langiq, it is definitely clear that Ruallette is the abode of the gods [11]. The repetition of the model above is, of course, not only understood as mere word reproduction, but rather the repetition contains meaning based on syntactic and semantic patterns.

\subsubsection{Time Marking Recurrence Technique}

The formula in the form of time marking repeated by passureq can be seen in the La Galigo poem excerpt below:

Kua mua pi ronnang onronna le tikkaqe

Natakkadapiq ri Botting Langiq

Menreq manaiq ri sao kuta pareppaqe.

Sessuq nasompa wali natudang le ri olona Patotoqe.

The sun was still in place

Then he arrived at Boting Langiq

Continue to ride in the palace of Kuta Kuta Pareppaqe.

Prostration worshiped and then sat before Patotoqe.

The depiction of the transition or the beginning of a new event is also illustrated in the form of repeating time markers which are also at the same time event markers namely "Kua mua ronnang onronna le tikkaqe / the Sun when it is still in place" illustrates the time someone arrives in the celestial world to face Patotoqe. This repetition at the same time serves to describe the transition of events so quickly. Where previously it was said that the riselleng teacher and his wife were ordered to go up to Boting Langiq to meet Patotoqe. The order happened so fast that the ri selling teacher's trip to Boting Langiq was described very dramatically. That the ri selling teacher has reached the upper world just as the sun has not yet moved from its original place when the order was received by ri ri Selleq. 


\subsubsection{Rhythm Repeating Technique.}

In addition to the repetition or repetition techniques above, passureq also uses techniques related to how to play the rhythm or emphasis on certain parts. passureq has a different pattern of rhythm and intonation. These differences become their respective identities, for example Indo Masse when saying the name Sawerigading using a slow tempo by adding syllables (e: read long) in front of the name Sawerigading, becoming (eeeeee saweriiigaaading). This is different when Indo Masse mentions the shorter dewatae name with a faster tempo. The mention of dewatae does not use variations in intonation or rhythm.

\subsection{Passureq Social Life}

One passureq said that in the past passureq's social life still played an important role in the life of the Bugis community, especially in Wajo Regency. They consider that passureq is an honorable person because it can understand and chant the La Galigo sureq as an ancient text. So that the Wajo people always involve passureq in community events or activities such as marriage, aqiqah and moving house. Before the celebration is held the community will visit the passureq house to ask for guidance in determining the good day of the celebration based on the content of sureq la galigo. At the time of the celebration, passureq was again involved in filling the celebration with massureq. Massureq in this case functions as a medium to convey ancestral messages and as a means of entertainment.

At present, passureq's social life is far different. If in the past a passureq was still very much needed and the words were still very obeyed, whereas now the community does not care much anymore, although now there are still those who involve passureq in the celebration and other activities but are not as famous as before. This is influenced by technological developments and modernization.

However Passureq has a special position in the eyes of the people who have not changed until now, especially in the people who adhered to Tolotang religion in Bulo Village, Maniang Pajo District, Wajo Regency. For the people of Bulo Village passureq still has a special position that is considered important, Passureq is considered to be able to solve problems related to spiritual issues [12]. Passureq is used as an advisor when there are certain rituals that the Tolotang community wishes to carry out. This is related to determining the good or bad day for the implementation of a ritual. The rituals meant are ball macceraq, macceraq ase, ball menre, and mappabotting. Before starting the ritual, passureq is first asked to open the La Galigo manuscript and read it in front of people who want to carry out the ritual, and then determine the day that can be used to start a ritual.Passureq can also be said as a teacher in informal education because Passureq conducts teaching activities for children around its home. The things taught include how to read a script or sureq accompanied by tones as well as techniques in playing tones so that they are of artistic value and touch the listener. In addition, it also teaches good ways of performing so that the children can become a reliable passureq.

\section{Conclusion}

When Indo Masse experienced periods of introduction to the massureq tradition through his accidental listening to neighbors who were massureq, at that moment the memory of tone, rhythm, and melody began to build up in him. It becomes permanent when he starts to chant various words based on his listening experience. Indo Masse's actions at that time could be said to be an expression of spontaneity and in response to sensing experiences. So Indo Masse 
in the end really pursued the massureq tradition, but he still used traditional standards embedded in his memory.

Broadly speaking, it is divided into three stages: opening including greetings, prayer readings, and permission to a popular audience called mappatabe. Then the contents include a comprehensive telling of the context or theme raised, and finally the closing, which is mostly infiltrated with messages.

Symbolic movements touching the mouth, nose and fontanel have a deep order of meaning in the beliefs of the Bugis community. These three parts of the body are considered as the way out of the breath or the human spirit which is also interpreted as the key to the life of a body.

Passureq in chanting the La Galigo text as poetry lines when massureq performs repetition or repetition techniques as a formula. The formula triggers Passureq's memory to become like a rote memory for her. The formula used by Passureq has been structured in such a way that is structurally in their minds, so that the massureq in various places always sounds the same.

Passureq in the social view of the Bugis community, specifically the view of the community where Passureq lives in the village of Buloe, Maniang Pajo district, Wajo Regency. Passureq's social life as one part of the community group basically Passureq's life is not much different from other communities. Passureq is seen from an economic perspective as a very simple society. In the past, passureq's social life played an important role in the life of the Bugis community, especially in Wajo Regency. A passureq is considered a respectable person and always involves passureq in the celebration or activity of the community.

\section{References}

[1] A. Mardi, "Islam \& Cultural Traditions in South Sulawesi," J. Adab., vol. vol x no 2, 2010.

[2] L. B. Albert, The Singer of Tales. New York: Antheneum, 1976.

[3] A. M. Akhmar, "Toloq Rumpaqna Bone Text and Translation Edits and Study of Literacy and Literacy," Gadjah Mada Univesity, 1998.

[4] F. Ambo Enre, Ritfeedna Welenrennge, A Galigo Classic Bugis Literary Episode. Jakarta: Indonesian Torch Foundation, 1999.

[5] Ashari, "Study of the Meaning of Sawerigading Folklore as a Code of Community Behavior (A Semantic Study)," Hasanuddin Ujung Pandang University, 1993.

[6] C. A. Mayura, "Self Names in the Text of La Galigo Episodes of the Beginning of Tau (A Semantic Study)," Hasanuddin Ujung Pandang University, 2012.

[7] N. Rahman, "Love the Sea and Power," Hasanuddin Ujung Pandang University.

[8] N. Rahman, Sureq Art and Culture. Makassar: La Galigo Press, 2008.

[9] N. Rahman, Sureq "Revitalizing Culture Towards Strengthening Local Cultural Roots". Initial Edition. Makassar: La Galigo Press, 2008.

[10] A. Teeuw, "Literature in Tensions between Tradition and Renewal," Basis June Ed., vol. XXVI, No., 1978.

[11] Y. T. Yapi, Study of oral literature. Yogyakarta: Lamarela, 2011.

[12] Firmansyah, "Nilai-Nilai Solidaritas dalam Upacara Maccera' Tappareng di Danau Tempe, Kab. Wajo," Hasanuddin University Makassar, 2012. 